\title{
IMPLANTATION AND DEVELOPMENT OF MOUSE EGGS TRANSFERRED TO THE UTERI OF NON-PROGESTATIONAL MICE
}

\author{
THOMAS P. COWELL* \\ Department of Zoology, University of Oxford, and \\ Department of Anatomy, University of California Medical Center, San Francisco
}

(Received 16th May 1968)

Summary. Four-day-old mouse embryos were transferred to the uterine lumen of virgin cyclic and ovariectomized mice; the eggs 'implanted' and developed only in mice whose endometrium was previously traumatized with a glass scraper. The histology of the mechanically induced implantation sites is described and similarities to normal implantation sites are discussed.

Implanted embryos developed only to stages equivalent to 5 to 9 days of normal pregnancy, but the trophoblast continued to proliferate and invaded the endometrium, eroding maternal blood vessels and distending the uterus. In five of eight ovariectomized mice, plaques of decidual-like cells were found near the trophoblast 7 to 12 days after transfer.

\section{INTRODUCTION}

Experimental separation of maternal and embryonic elements provides a valuable means for studying the embryo-endometrial relationship during implantation and placentation.

Transplantation of the egg to extra-uterine sites such as the anterior chamber of the eye (Fawcett, Wislocki \& Waldo, 1947; Runner, 1947), kidney (Fawcett, 1950), spleen (Kirby, 1963b) and testis (Kirby, 1963a) demonstrates that the egg is capable of 'implantation' and limited development in a variety of nonendometrial tissues, apparently regardless of the hormonal environment.

The comparative ease of egg implantation in the extra-uterine sites contrasts with implantation in the uterus which occurs only during an endocrinologically controlled receptive period (Doyle, Gates \& Noyes, 1963; Psychoyos, 1966). However, several investigators have observed implantation of tumours in cyclic mice (Hall, 1940; Stein-Werblowsky, 1962). Hall (1940) thought that sarcoma implantation in the cyclic uterus occurred at sites where the trocar used for transfer had damaged the uterine lining.

The following experiment was designed to determine if eggs would implant on the damaged endometrial lining of the non-progestational mouse uterus

\footnotetext{
* Present address : Department of Pathology, Harbor General Hospital, Torrance, California.
} 
and, if so, to study the process of implantation, the development of the conceptus, and the effect of the developing conceptus on the uterus in this abnormal conceptus-endometrium relationship.

\section{METHOD}

The experiments were performed on young, sexually mature, virgin $\mathrm{C} 3 \mathrm{H}$ and randomly bred mice from a hybrid colony.

Unimplanted eggs were obtained from the uterus of donor mice at about midnight 4 days after mating, at which time the mouse egg loses the zona pellucida (Wilson, 1963). The eggs were kept in Pannett-Compton saline solution at room temperature until transfer to the uterine lumen of recipient mice, which took place within $1 \mathrm{hr}$.

Haemangio-endotheliomata were taken from $129 / \mathrm{J}$ mice and placed in Pannett-Compton saline. The tumours were cut into $1-\mathrm{mm}$ pieces and transferred to the traumatized left uterine horn of each of eight ovariectomized mice.

Bilateral ovariectomy was performed on the recipient mice by excising the ovarian fat pad. Vaginal smears of all cyclic recipient mice were taken before the transfer operation.

The recipient mouse was anaesthetized with an intraperitoneal injection of Avertin (Winthrop), and the left uterine horn exposed through a dorsolateral incision. A small tear was made in the uterus near the utero-tubal junction and a scraper, fashioned from a glass pipette (Pl. 1, Fig. 1), was inserted through the tear to about two-thirds of the way down the uterine lumen. Then, with the cutting edge pressed against the uterine lining, the scraper was withdrawn. The instrument was rotated and the process repeated four more times. The size of the scraper used was, as a rule, as large as possible, while still allowing its free movement down the uterine lumen. Immediately after scraping, six to twenty eggs were introduced into the left uterine horn by means of a transfer apparatus described by Kirby (1963b). The tip of the micropipette used in the transfer of the eggs was flame polished to reduce the chance of its insertion into the endometrium. All instruments were sterilized before the operation.

Autopsy was performed between half a day and 25 days after transfer. The uterus and ovaries were fixed in Bouin's solution, embedded, serially sectioned at $8 \mu$ and stained with Haematal 8 and Biebrich scarlet.

\section{RESULTS}

\section{Endometrial damage}

Examination of the cyclic uterus 12 to $14 \mathrm{hr}$ after traumatization revealed that the endometrium was damaged in focal areas, most of which were in the ovarian end of the left uterine horn. Although the epithelium covered most of the endometrium, it was very attenuated in many areas, especially where the endometrium was very oedematous. There was usually oedema, and leucocytic infiltration occurred in the endometrium underlying broken epithelium. In some areas, the myometrium was degenerative and oedematous. 
In the ovariectomized mice, much more of the epithelium was absent or degenerative and there was a great deal of exudate oozing into the uterine lumen from the oedematous endometrium.

\section{Implantation}

The process of implantation, narrowly construed, involves the attachment of the egg to, and the subsequent removal of, the uterine epithelium. Here, implantation differs from the normal process mainly with respect to the exclusion of the removal of the epithelium owing to its prior mechanical removal.

Table 1 summarizes the incidence of implantation of eggs in damaged and intact uteri in cyclic mice at autopsy less than 1 day after transfer.

The orientation of all seven implanting eggs in Table 1, Group 1, was with

TABLE 1

THE INGIDENCE OF EGGS IMPLANTING ON TRAUMATIZED AND INTACT ENDOMETRIUM DURING DIFFERENT STAGES OF THE OESTROUS GYGLE

\begin{tabular}{c|c|c|c|c|c|c}
\hline $\begin{array}{c}\text { Stage of } \\
\text { oestrous cycle } \\
\text { at transfer }\end{array}$ & $\begin{array}{c}\text { No. of } \\
\text { recipient } \\
\text { mice }\end{array}$ & $\begin{array}{c}\text { No. of } \\
\text { mice in which } \\
\text { eggs implanted }\end{array}$ & $\begin{array}{c}\text { \% of mice } \\
\text { in which } \\
\text { eggs implanted }\end{array}$ & $\begin{array}{c}\text { No. of } \\
\text { eggs } \\
\text { transferred }\end{array}$ & $\begin{array}{c}\text { No. of } \\
\text { implanted } \\
\text { eggs }\end{array}$ & $\begin{array}{c}\% \text { of } \\
\text { eggs } \\
\text { implanted }\end{array}$ \\
\hline Group 1 & 3 & 2 & 66 & & & 72 \\
Di-oestrus & 2 & 2 & 100 & 30 & 4 & $13 \cdot 3$ \\
Pro-oestrus & 2 & 0 & 0 & 30 & 0 & 0 \\
Oestrus & 2 & 0 & 0 & 15 & 0 & 0 \\
Metoestrus & 9 & 4 & $44 \cdot 5$ & 117 & 7 & 6 \\
Total & & & & & & \\
\hline Group 2 & 3 & 0 & 0 & 56 & 0 & 0 \\
Di-oestrus & 2 & 0 & 0 & 27 & 0 & 0 \\
Pro-oestrus & 2 & 0 & 0 & 35 & 0 & 0 \\
Oestrus & 1 & 0 & 0 & 15 & 0 & 0 \\
Metoestrus & 8 & 0 & 0 & 133 & 0 & 0 \\
Total & 0 & 0 & & \\
\hline
\end{tabular}

Group 1: Uterine lining scraped before transfer: autopsy less than 1 day after transfer.

Group 2: Controls-uterine lining intact: autopsy 1 day after transfer.

attachment at the abembryonic pole (Pl. 1, Fig. 2). Implantation occurred on the mesometrial, lateral and antimesometrial sides of the uterus.

The morphology of the uterine wall at nineteen implantation sites was studied in thirty-three mice less than 3 days after the transfer of eggs. In seventeen of the nineteen sites, the epithelium was broken or degenerative and the underlying stroma oedematous. In the remaining two implantation sites, the epithelium was intact and no oedema was evident in the underlying stroma.

\section{Development}

Table 2 summarizes the effect of trauma on the incidence of development of eggs transferred to the uterine lumen of cyclic and ovariectomized mice.

The first gross indication of a developing conceptus was the appearance, about 3 days after transfer, of a haemorrhagic mass in the uterus which increased in size for the next 4 to 9 days and distended the uterus, in several cases to over $5 \mathrm{~mm}$ in diameter. The veins draining the mass were markedly dilated. 
Embryonic development proceeded to a stage equivalent to a 5- to 6-day-old embryo of normal pregnancy (Snell, 1956) in seven cases (PI. 1, Fig. 3). In only two cases did the embryo develop past a stage equivalent to a 5- to 6-day embryo of normal pregnancy. These embryos were equivalent to 8- to 9-day stages (Pl. 1, Fig. 4). Trophoblast continued to proliferate from the ectoplacental cone after the death of the embryo.

\section{TABLE 2}

THE EFFECT OF TRAUMATIZING THE UTERUS ON THE INCIDENCE OF DEVELOPMENT OF EGGS TRANSFERRED TO THE UTERINE LUMEN

\begin{tabular}{l|c|c|c|c|c|c}
\hline $\begin{array}{c}\text { Stage of } \\
\text { oestrous cycle } \\
\text { at transfer }\end{array}$ & $\begin{array}{c}\text { No. of } \\
\text { recipient } \\
\text { mice }\end{array}$ & $\begin{array}{c}\text { No. of } \\
\text { mice in which } \\
\text { eggs developed }\end{array}$ & $\begin{array}{c}\text { \% of mice } \\
\text { in which } \\
\text { eggs developed }\end{array}$ & $\begin{array}{c}\text { No. of } \\
\text { eggs } \\
\text { transferred }\end{array}$ & $\begin{array}{c}\text { No. of } \\
\text { eggs } \\
\text { developed }\end{array}$ & $\begin{array}{c}\% \text { of } \\
\text { eggs } \\
\text { developed }\end{array}$ \\
\hline Group 1 & 26 & 5 & 19 & 221 & 7 & $3 \cdot 2$ \\
$\quad$ Di-oestrus & 26 & 8 & 53 & 107 & 7 & $6 \cdot 5$ \\
Pro-oestrus & 15 & 2 & 18 & 91 & 2 & $3 \cdot 3$ \\
Oestrus & 11 & 1 & 20 & 59 & 1 & $1 \cdot 7$ \\
$\quad$ Metoestrus & 5 & 16 & 29 & 478 & 17 & $3 \cdot 6$ \\
Total & 57 & 100 & 77 & 14 & $18 \cdot 3$ \\
Ovariectomized & 6 & 6 & 100 & & & \\
\hline Group 2 & & 0 & 0 & 76 & 0 & 0 \\
$\quad$ Di-oestrus & 7 & 0 & 0 & 37 & 0 & 0 \\
$\quad$ Oestrus & 3 & 0 & 0 & 113 & 0 & 0 \\
Total & 10 & 0 & & & & \\
\hline
\end{tabular}

Group 1: Uterine lining scraped before transfer; autopsy between 3 and 25 days after transfer. Group 2: Control-uterine lining intact; autopsy 5 days after transfer.

Small lacunae of red blood cells in the interstitial spaces of the trophoblast and seepage of red blood cells into the neighbouring endometrium indicated that the trophoblast had started to erode the blood vessels by 2 days after transfer. Trophoblast giant cells proliferated from the ectoplacental cone between the 3rd and 8th day of graft life and formed a large blood-filled reticulum. Blood and exudate escaped from the reticulum into the uterine lumen in every case examined. A layer of coagulated blood formed around the outside

\section{EXPLANATION OF PLATE 1}

FIG. 1. One of the scrapers used for traumatizing the endometrium. The scrapers were fashioned from glass pipettes. $\times 1.5$.

FIG. 2. Egg attached abembryonically to the mesometrial side of a pro-oestrous uterus receiving endometrial trauma before transfer of eggs to the uterine lumen. Note the oedematous, but non-decidualized endometrium around the implantation site and the dilated vessels in the mesometrium, $\times 175^{\circ}$.

Fig. 3. Two embryos, equivalent to about $5 \frac{1}{2}$-day embryos of normal pregnancy, found in contact with one another in the uterus of an ovariectomized mouse 3 days after endometrial trauma and the transfer of eggs to the uterine lumen. Note the trophoblast giant cell with the double nucleus invading between the endometrial glands. $\times 210$.

Fig. 4. Exceptional development of an embryo in the endometrium of a cyclic uterus. This embryo, which is equivalent to a normal 8-day-old embryo, was developing in a mouse 5 days after transfer. Note the gradual attenuation and degeneration of the epithelium over the trophoblast. There is exudate oozing into the uterine lumen, some of which can be seen in the lower right hand corner. $\times 140$.

Fic. 5. Tissue resembling decidua in the uterus of an ovariectomized mouse 8 days after transfer. Note the two trophoblast giant cells at the top of the picture. $\times 450$. 


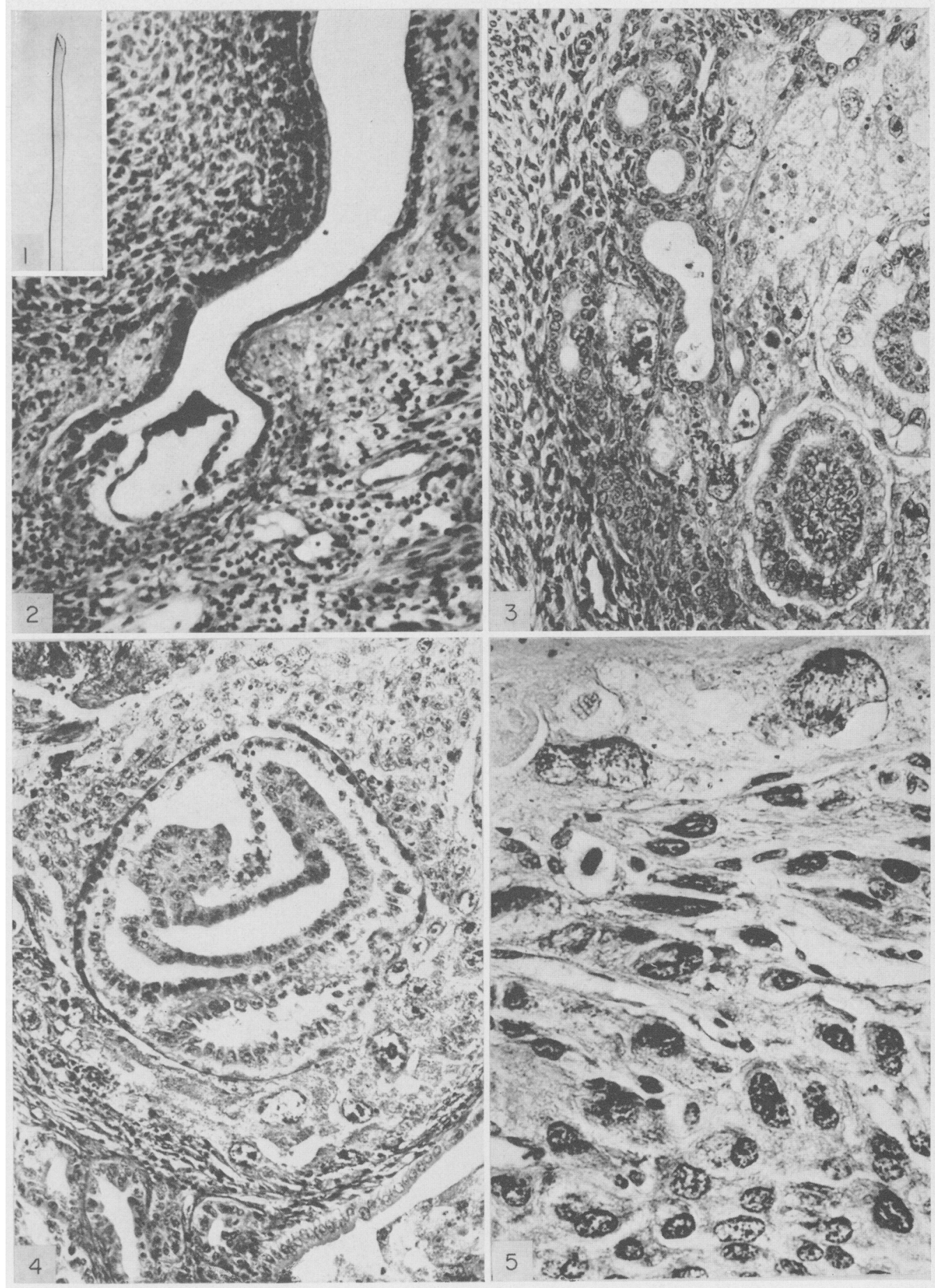

(liacing 1). 242 
of the reticulum. Some viable trophoblast was present in a mouse on which autopsy was performed 25 days after transfer, although much of the trophoblast was necrotic.

\section{Effect of the conceptus on the endometrium}

The endometrium near developing conceptuses resembled the more distant endometrium in all of the intact and ovariectomized mice on which autopsy was performed less than 6 days after transferring eggs to the uterus.

Near the developing conceptus, there were plaques of cells much resembling decidual cells (Pl. 1, Fig. 5) in five of eight ovariectomized mice 7 to 12 days after transfer. The cells were large with abundant non-vacuolated cytoplasm, had large nuclei with peripheral chromatin and were of various sizes. Also, there were binucleated cells with multiple nucleoli.

By contrast, there were no plaques of decidual tissue near the haemorrhagic haemangio-endotheliomata growing in the endometrium of five mice 9 days after transplantation of the tumour tissue.

\section{DISCUSSION}

These results show that the mouse egg transferred to the uterine lumen of cyclic and ovariectomized mice is able to implant and develop, provided that the wall is damaged. It is unlikely that eggs can implant and develop in the non-progestational, non-traumatized uterus. The frequency of implantation and development of mouse eggs transferred to traumatized uteri differed significantly $(P<0.01)$ from that in non-traumatized uteri. Implantation has never been reported in non-progestational uteri, e.g. in mice ovariectomized immediately after mating and after induced ovulation in prepuberal mice (Smithburg \& Runner, 1960).

Endometrial trauma resulted in changes which are in some respects similar to, but more drastic than, the endocrinologically induced endometrial changes which are associated with receptivity to implantation during normal pregnancy in the mouse. In normal pregnancy, the endometrium in the mouse and in many other species becomes hyperaemic and oedematous at the receptive site (Mossman, 1937). The epithelium of deciduomata induced by oil injections in mice degenerates in the absence of the egg at the base of the implantation crypt at the same time as epithelial erosion occurs in normal pregnancy (Finn \& Hinchliffe, 1965). In the present experiment, almost $90 \%$ of the eggs implanted in the uteri at sites where the epithelium was either broken or extremely attenuated and where the underlying endometrium was oedematous. Furthermore, this was the only type of site where the egg was observed to develop.

Eighteen per cent of eggs transferred to the uteri of ovariectomized mice receiving endometrial trauma implanted and developed, whereas only $3.6 \%$ of eggs transferred to cyclic mice receiving endometrial trauma implanted and developed. The much greater areas of broken and degenerating endometrial epithelium and stromal oedema observed in the ovariectomized mice possibly contributed substantially to the increased incidence of implantation in ovariectomized mice. 
The pathological development of the ovum in the non-progestational uteri demonstrates that hormonal preparation of the uterus is necessary for normal development of the ovum.

Study of the requirements of deciduoma formation in the rat indicates that the uterus must be primed by progesterone before decidualization will occur in response to trauma (Psychoyos, 1966). Since, in the mouse, the endometrium is primed for decidualization by progesterone produced by the ovaries, it was interesting to find patches of decidual tissue near the trophoblast reticulum 7 to 12 days after transferring eggs to the uterus of ovariectomized mice. In view of the evidence suggesting that mouse and rat trophoblast giant cells produce progesterone, it is very possible that the endometrium in the ovariectomized mice was primed by progesterone produced by trophoblast giant cells (Deane, Rubin, Driks, Lobel \& Leipsner, 1962).

As the endometrium of ovariectomized mice did not decidualize near haemorrhagic haemangio-endotheliomata, it seems unlikely that the decidualization near trophoblast is the result of a non-specific effect of a foreign tissue growing in the endometrium, or increased endometrial localization of progesterone produced by the adrenals.

\section{ACKNOWLEDGMENTS}

This work was supported by USPHS Grant 5T5-GM 43-04 and the Medical Research Council, England.

I wish to thank Professor Pringle, F.R.s., for laboratory space in his department where most of the work was carried out, and I am deeply indebted to Dr D. R. S. Kirby for his teaching, stimulating discussions and the use of his laboratory and to Miss Michaela Simmersbach for her skilful technical help. I thank Dr Laurel Glass also for her helpful advice and Dr Vince DeFeo for his opinion on the decidual appearing tissue.

\section{REFERENCES}

Deane, H. W., Rubin, B. L., Driks, E. C., Lobel, B. L. \& Leipsner, G. (1962) Trophoblastic giant cells in placentas of rats and mice and their probable role in steroid-hormone production. Endocrinology, 70, 407.

Doyle, L. L., Gates, A. H. \& Noyes, R. W. (1963) Asynchronous transfer of mouse ova. Fert. Steril. $14,215$.

FAwCETT, D. W. (1950) The development of mouse ova under the capsule of the kidney. Anat. Rec. 108, 71 .

Fawcett, D. W., Wislocki, G. P. \& Waldo, C. M. (1947) The development of mouse ova in the anterior chamber to the eye and in the abdominal cavity. Am. F. Anat. 81, 413 .

Finn, C. A. \& Hinchliffe, J. R. (1965) Histological and histochemical analysis of the formation of implantation chambers in the mouse uterus. F. Reprod. Fert. 9, 301.

HALL, B. V. (1940) Influence of the oestrous cycle and the decidual reaction on intrauterine tumours in mice. Yale 7. Biol. Med. 13, 333.

KIRBY, D. R. S. (1963a) The development of mouse blastocysts transplanted to the scrotal and cryptorchid testis. 7. Anat. 97, 119.

KIRBy, D. R. S. (I963b) Development of the mouse blastocyst transplanted to the spleen. F. Reprod. Fert. 5, 1.

Mossman, H. W. (1937) Comparative morphogenesis of foetal membranes and accessory uterine structures. Contr. Embryol. 26, 129. 
Psycноуоs, A. (1966) Recent researches on egg implantation. In: Egg Implantation, Ciba Foundation Study Group No. 23, Churchill, London.

Runner, M. (1947) The development of mouse eggs in the anterior chamber of the eye. Anat. Rec. 98, 1.

SmithbuRG, M. \& RunNer, M. (1960) Retention of blastocysts in nonprogestational uteri of mice. F. exp. Zool. 43, 21.

SNell, G. D. (1956) Biology of the laboratory mouse, p. 6. Dover, New York.

Stein-Werblowsky, R. (1962) The receptivity of the endometrium to implantation. $\mathcal{F}$. Obstet. Gynaec. Br. Commonw. 69, 107.

WrLson, I. B. (1963) A new factor associated with the implantation of the mouse egg. F. Reprod. Fert. 5, 281. 